\title{
Discipline and Punish at Camp: Citizenship and the Issue of Violence at a Swedish Boy Scout Camp
}

\author{
Björn Lundberg
}

\begin{abstract}
This article examines reports of physical punishment at the national Swedish Boy Scout camp Åvatyr in 1950. The Swedish newspapers Dagens Nyheter and Expressen described the events in terms of bullying and violence, while the camp directors declared that the reports were merely exaggerated accounts of innocent pranks and practical jokes. This article draws information from newspaper articles, Scout magazines and archival sources to discuss how the incidents at the Åvatyr camp tapped into a debate on disciplinary measures against children in Sweden. The analysis also concerns how these acts of punishment related to the Boy Scouts' scheme of citizenship instruction. Finally, the long-term effects of this purported scandal are evaluated, including a call for reform of masculinity and citizenship ideals within the Boy Scout movement during the following decade.
\end{abstract}

Keywords $\bullet$ boy scouts, camp, citizenship, self-government, violence

\section{Introduction}

In the summer of 1950, around 10,000 Boy Scouts and Scout leaders from twelve countries gathered near Tyresö in Sweden for what was hitherto the largest camp arranged by the Swedish Scout Association (Sveriges Scoutförbund). Reporters from several newspapers covered the opening ceremony and the largest Swedish morning paper Dagens Nyheter featured the story on its front page. ${ }^{1}$

While these reports provided valuable publicity in a time of stagnating membership figures for the Swedish Scout Association, media attention turned in a surprising direction within the next few days. Reports of public punishments and humiliation at Åvatyr sparked a debate about bullying among the Boy Scouts. ${ }^{2}$

The purpose of this article is to analyse the educational ideals of the Swedish Boy Scout movement during the early post-war era through the example of this highly publicised incident of punishment at the Åvatyr camp. More specifically, attention will be given to the role of self-governance and character training at camp. This approach, inspired by the study of "microphysics of power," is chosen because the incident and its aftermath convey important knowledge not only of the educational

This article expands on a camp incident previously discussed in the author's doctoral thesis: Björn Lundberg, Naturliga medborgare: Friluftsliv och medborgarfostran i scoutrörelsen och Unga Örnar 19251960 (Lund: Arkiv, 2018).

1 Dagens Nyheter, July 24, 1950.

2 For general accounts of the state of the Boy Scout association in Sweden during these years, including membership figures: Göran Sidebäck, Kampen om barnets själ: Barn- och ungdomsorganisationer för fostran och normbildning 1850-1980 (Stockholm: Carlsson, 1992), 75, 84. Margareta Puke, Scoutings historia (Stockholm: Sv. scoutförb., 1982); Georg Sterzel and Raoul Neveling, Skördetid och framtidstro (Stockholm: Föreningen scoutmuseets vänner årsskrift, 2005). See also Sveriges flickors scoutförbunds historia 1913-1953, Instruktionsserie för ledare 6 (Stockholm: Sveriges flickors scoutförbund, 1954).

Björn Lundberg is a PhD in History at the Department of History, Lund University, Sweden. Email: bjorn.lundberg@hist.lu.se 
practices of the Boy Scout movement, but notions of Swedish post-war childhood in general.

The analysis is divided into three sections. The first part presents the setting and discusses the educational ideals of the Swedish Boy Scout movement. What was the perceived importance of self-governance and discipline within its citizenship education? The second part gives an in-depth description of the events at the Åvatyr camp and details why the events were ultimately framed as a scandal in the press. The third and final section of the article details the aftermath of the events at Âvatyr and its long-term consequences. This section discusses how the Boy Scout organisation dealt with the negative attention and what conclusions were drawn after the camp had ended. The argument is that the events at Åvatyr contributed to a re-evaluation of masculine ideals in the Swedish Scout Association that eventually contributed to the dissolution of gender-divided scouting in Sweden in favour of a co-educational movement.

This article draws information from newspapers and Scout magazines, as well as a contemporary camp journal written by a Boy Scout patrol. Thanks to the varied source material, it is possible to study the events at Åvatyr from a multi-layered perspective. Reports from the Åvatyr camp were published in all major Swedish daily newspapers, and the events were covered and discussed in-depth by Dagens Nyheter and the evening tabloid Expressen, both published by the Bonnier Group and featuring liberal editorial pages. ${ }^{3}$ The camp journal was kept by the patrol Hackspetten, from Eslövs scoutkår. In the journal, every day at camp was detailed in several hand-written pages, shifting between amusing incidents and mundane reports. Also featured were a few black-and-white photographs glued to the pages. Despite this, the sources at hand provide limited and sometimes contradictory explanations of the actual events that took place at Åvatyr. However, the texts discussed here also act as sources for why these events were conceived of as problematic, and how the incidents gave rise to a public debate on bullying.

\section{Perspective and theoretical framework}

By analysing the mechanisms of discipline and punishment in a localised historical setting, this article draws inspiration from the works of Michel Foucault, who famously described the central issue of government in the modern world as "the conduct of conduct." 4 Power in this sense operates productively, creating and recreating self-regulatory movements and actions, shaping desires and norms. In other words, disciplinary power became intrinsically self-disciplinary. ${ }^{5}$ Adding to this analysis of power, Foucault in later years started to develop a theory of government in liberal society known as governmentality. This field of inquiry has closely examined how rationalities of government came to act through personal freedom. ${ }^{6}$ However,

3 Overviews of the Swedish newspaper market in the postwar era are presented in: Claes-Göran Holmberg, Ingemar Oscarsson, Per Rydén, En svensk presshistoria (Stockholm: Esselte studium, 1983); Karl Erik Gustafsson and Per Rydén, eds., Den svenska pressens historia. 4, Bland andra massmedier (Stockholm: Ekerlid, 2002).

4 Quoted in Colin Gordon, "Governmental Rationality: An Introduction," in The Foucault Effect: Studies in Governmentality, ed. Graham Burchell, Colin Gordon, and Peter M. Miller (Chicago: University of Chicago Press, 1991), 48.

5 Lisa Blackman, The Body (Oxford: Berg, 2008), 25-27.

6 Michel Foucault, "Governmentality", in The Foucault Effect: Studies in Governmentality, ed. G. Burchell, C. Gordon, and A. Miller (Chicago: University of Chicago Press, 1991); Mitchell Dean, 
as Mitchell Dean and other scholars have pointed out, multiple rationalities of government may be enforced in different settings, or even simultaneously. This makes it clear that the question of how the governing of children operates in a certain time and place must ultimately be an empirical question. ${ }^{7}$

Scouting emerged in Britain during the first decade of the twentieth century. Within a decade, this youth movement designed for boys spread across the globe and attracted girls as well, who were organised in separate Girl Guide or Girl Scout groups. ${ }^{8}$ Since their inception, scouting and guiding have attracted more than 500 million children and leaders, as "two of the most distinctive global social phenomena of the twentieth century." ${ }^{9}$ While the early history of the Scout movement has drawn increased scholarly attention, the movement's post-war history has not been covered extensively. ${ }^{10}$ One of the general trends in global scouting during the last half-century has been increased attention to co-educational reform, with the Scout Association from the UK opening all age groups for boys and girls in 2007, to commemorate the movement's centennial. In Sweden, the two largest organisations for Boy Scouts and Girl Scouts merged in 1960, paving way for full co-educational reform during the following two decades. In this context, the Swedish Scout movement provides a relevant example to the study of co-educational integration.

This article will discuss the events of the Åvatyr camp in relation to changing notions of citizenship and masculinity in the Swedish Boy Scout movement. There is, however, also reason to consider the changing attitudes regarding disciplinary measures in Swedish public education and society at large. While Sweden had not actively participated in the Second World War, the early post-war period brought profound changes to Swedish educational debate, reflecting the experiences of German Nazism and the horrors of war. In the final report presented by the 1946 Schools Commission, earlier ideals of obedience, loyalty and patriotism had been supplanted by an overarching ambition to foster democratic citizens. Critical thinking and self-reliance were presented as active measures to counter the future growth of authoritarian ideologies. ${ }^{11}$

Governmentality: Power and Rule in Modern Society (Thousand Oaks, CA: SAGE Publications, 2010); Michel Foucault, Security, Territory, Population: Lectures at the Collège De France, 1977-1978 (New York: Palgrave Macmillan, 2007). Nikolas Rose, Governing the Soul: The Shaping of the Private Self (London: Routledge, 1989).

7 Mitchell Dean, "Liberal Government and Authoritarianism," Economy and Society 31, no. 1 (2002).

8 In Britain, the term Girl Guides has been used throughout the movement's history, while the organisation became known as Girl Scouts in the United States. The Swedish term flickscout translates as "girl scout." Tammy Proctor, Scouting for Girls: A Century of Girl Guides and Girl Scouts (Santa Barbara, CA: Praeger, 2009).

9 Allen Warren, "Foreword: Understanding Scouting and Guiding after a Hundred Years," in Scouting Frontiers: Youth and the Scout Movement's First Century, ed. Nelson R. Block and Tammy M. Proctor (Newcastle: Cambridge Scholars, 2009). For global membership figures: Tim Jeal, Baden-Powell: Founder of the Boy Scouts, 2nd US edition (New Haven: Yale University Press, 2001[1989]), ix.

10 Studies that specifically address changes in Scouting during the first decades after the Second World War include Jeffrey Bonhomme, "In Step with Canada's Future:" The Restructuring of the Boy Scout Movement in Canada" (1992), Electronic Theses and Dissertations 6833; Jennifer Helgren, American Girls and Global Responsibility: A New Relation to the World during the Early Cold War (New Brunswick: Rutgers University Press, 2017); Sarah Mills, "Be Prepared: Communism and the Politics of Scouting in 1950s Britain," Contemporary British History 25, no. 3 (2011), 429-50.

11 Jonas Qvarsebo, Skolbarnets fostran: Enhetsskolan, agan och politiken om barnet 1946-1962 (Linköping: Linköpings universitet, 2006); Johan Östling, Nazismens sensmoral: Svenska erfarenheter i andra världskrigets skugga (Stockholm: Atlantis, 2008), 169-174. 
In relation to this, the early post-war era also brought changes to attitudes regarding disciplinary measures, corporal punishment and the regulation of peer relations in Swedish education. ${ }^{12}$ While there is no consensus in Swedish historiography of education as to how profound these changes were, earlier research has shown that the post-war decades were characterised by more lenient attitudes to authority and discipline. ${ }^{13}$ In 1958, a new law prohibited corporal punishment in the Swedish elementary school system. Due to the increased influence of psychology and educational theory, the pedagogical objective in Swedish primary education gradually shifted from external behaviour to personal development. ${ }^{14}$ Youth problems, which had previously been debated in terms of moral crises, were increasingly intertwined with new understandings of youth problems based on psychological and psychiatric expertise. According to Anna Larsson, bullying and problematic peer-relations became conceived of as educational problems in Swedish schools during the 1960s, which illustrates that these changes were not necessarily immediate. ${ }^{15}$

\section{Citizenship and educational ideals of the Boy Scout movement}

Scouting emerged in Britain during the decade prior to the outbreak of the First World War, as a programme for character training for British boys. Robert Baden-Powell, who had gained the status of war hero during the Second Boer War, wanted to reform British youth by introducing a method inspired by his experiences of imperial warfare. In 1908 he published the handbook Scouting for Boys, which immediately became a bestseller and gave rise to a new youth movement. ${ }^{16}$

Baden-Powell's objective was to reform British boyhood in order to secure the future strength of the empire. Physical and moral degeneration were to be combated through healthy outdoor exercises, and by inducing a sense of patriotic duty. According to the American scholar Michael Rosenthal, the Boy Scouts were thus "born in the anxieties of an imperial power." ${ }^{17}$ In his exhaustive analysis of European masculinity at the turn of the last century, George Mosse described scouting as a programme that sought to inculcate British working-class boys with the values and ethos of the British public school system: manly virtue through obedience, duty and endurance. ${ }^{18}$ Rosenthal went even further by claiming that the basis for the Scouts'

12 Qvarsebo (2006), 69-83.

13 Esbjörn Larsson, “Barn från Mars: Skolungdomens vapenövningar," Militärhistorisk tidskrift 2013 (Stockholm: Försvarshögskolan, 2014), 157; Joakim Landahl, Auktoritet och ansvar: Lärares fostrans- och omsorgsarbete i historisk belysning (Stockholm: Arbetslivsinstitutet, 2006), 218.

14 Mats Sjöberg, “Att fostra ett skolbarn: Den nya skolan och barndomens förändring 1950- 1970," in Barnets bästa: En antologi om barndomens innebörder och välfärdens organisering, ed. Bengt Sandin and Gunilla Halldén (Stockholm/Stehag: Symposion, 2003), 91-92.

15 Anna Larsson, "Mobbningfrågan i förändring: Efterkrigstidens synsätt på skolbarns kamratrelationer," Historisk tidskrift 130, no. 2 (2010), 241-64.

16 Tim Jeal, The Boy-Man: The Life of Lord Baden-Powell (New York: Morrow, 1990); Allen Warren, "Sir Robert Baden-Powell, the Scout Movement and Citizen Training in Great Britain, 1900-1920," The English Historical Review 101, no. 399 (1986); Nelson R. Block and Tammy M. Proctor, eds., Scouting Frontiers: Youth and the Scout Movement's First Century (Newcastle: Cambridge Scholars, 2009).

17 Michael Rosenthal, The Character Factory: Baden-Powell and the Origins of the Boy Scout Movement (London: Collins, 1986), 3.

18 George L. Mosse, The Image of Man: The Creation of Modern Masculinity (New York: Oxford University Press, 1996), 135. 
character and citizenship training, "indeed, what in most cases appears to be their sole constituent — was a firm sense of discipline." ${ }^{19}$

Other historians have challenged this disciplinary perspective by highlighting self-empowering aspects of the Scout method, especially with regard to Girl Scouting and Girl Guiding. ${ }^{20}$ The disciplinary perspective makes it difficult to explain why scouting was framed as an activity of freedom with outdoor life and countryside camps as key components to accomplish the "efficient and happy citizen." ${ }^{21}$ Why would an organisation obsessed with discipline and obedience focus on outdoor exercises as its primary tool for citizenship education?

From the perspective of governmentality, these disciplinary and emancipatory aspects of the Scout method do not appear to be a contradiction or pedagogical inconsistency. Instead, self-empowerment can be understood as a technique employed to achieve self-disciplined citizens, entwining the concepts of discipline and freedom. Outdoor life and camping can thus be regarded as techniques utilised by the Scout movement in its citizenship training programme as means to create a certain kind of citizen, prepared to become self-regulating and active subjects in liberal society. ${ }^{22}$

The survival skills that Scouts received training in were not primarily skills to be used for actual survival, but rather a metaphorical re-enactment of the ideal of the self-regulated and self-sufficient subject. Baden-Powell stated: "Our effort is not so much to discipline the boys, as to teach them to discipline themselves." 23 However, scholars of governmentality have pointed out that the means or methods applied to achieve self-disciplined and self-regulatory citizens could include disciplinary or event violent measures. Liberal governance should be regarded as an objective to be accomplished by both incentives and regulations. ${ }^{24}$

In order to achieve activity and self-reliance on the part of the boys, the Scout method included a certain degree of self-government. The basic unit for a scout group was a patrol of six to eight children, led by a patrol leader. This primus inter pares was to be selected based on leadership qualities and form a link between the scouts and the adult leaders. Patrol leaders gained special training and marked their status by donning exclusive details in their uniforms. According to Baden-Powell, the patrol system was based on the natural organisation of younger boys in gangs with an informal leader. ${ }^{25}$ In scouting, the aim was to harness and utilise the power of gang mentality for the public good and to foster boys into active citizens by instilling

19 Rosenthal (1986), 8.

20 Richard A. Voeltz, “The Antidote to 'Khaki Fever'? The Expansion of the British Girl Guides During the First World War," Journal of Contemporary History 27, no. 4 (1992); Allen Warren, "Mothers for the Empire:' The Girl Guides Association in Britain 1909-1939," in Making Imperial Mentalities: Socialisation and British Imperialism, ed. J.A. Mangan (Manchester: Manchester University Press, 1990). Tammy M. Proctor, "On My Honour: Guides and Scouts in Interwar Britain," Transactions of the American Philosophical Society 92, no. 2 (2002); Bodil Formark, Den välsituerade flickan: Om den svenska flickscoutrörelsens historia 1910-1940 (Lund: Sekel Bokförlag, 2010).

21 Robert Baden-Powell, Aids to Scoutmastership: A Handbook for Scoutmasters on the Theory of Scout Training (London: Jenkins, 1919).

22 Empowerment as a technology for citizenship is discussed in Barbara Cruikshank, The Will to Empower: Democratic Citizens and Other Subjects (Ithaca: Cornell University Press, 1999).

23 Robert Baden-Powell, Scouting for Boys: A Handbook for Instruction in Good Citizenship-the Original 1908 Edition (Oxford: Oxford: Oxford University Press, 2004), 212.

24 Dean (2002), 38.

25 Baden-Powell (1919). 
in them a sense of responsibility. Directly or indirectly, the Scout method of Robert Baden-Powell was also influenced by turn-of-the-century reform pedagogy. One of his inspirational figures was the American author and educationalist Ernest Thomson Seton, who had founded the Woodcraft Indians, a back-to-nature type of organisation intended for delinquent boys inspired by the educational ideas of progressive educationalists such as John Dewey. Baden-Powell managed to articulate these ideas of a regimen of citizenship instruction in a captivating and effectual narrative, thus making learning-by-doing a core element of the Boy Scout method. ${ }^{26}$

At the heart of the patrol system was the idea that boys could be taught moral lessons from their peers. Although the patrol system was the educational ideal of Baden-Powell, it took more than a decade before it was thoroughly implemented in the Swedish Boy Scout movement. When one Boy Scout leader looked back on the foundational years of scouting (in the 1910s) he remembered the excessive drill: "Evening after evening, exercises in marching and turning on a schoolyard." ${ }^{77}$ During the interwar years, the patrol system was implemented more whole-heartedly. The educational system of scouting was gradually consolidated. While the early Boy Scout movement had been entrenched in fiery nationalistic rhetoric, promulgated by the noted travel writer and conservative Swedish agitator Sven Hedin, the Boy Scout movement of the interwar era instead proposed a more jovial citizenship ideal based on the strengthening of mind, body and character through friluftsliv - healthy outdoor life. ${ }^{28}$

One of the most distinctive elements of the Boy Scout programme was its focus on the body. Physical activity and a healthy body were keys to successful citizenship. Consequently, the Scout method focused on citizenship as an activity, rather than a legal status. ${ }^{29}$ The focus of the body was also evident in Baden-Powell's advice on how to correct behaviour that he associated with bad citizenship: "The punishment for swearing and using bad language is for each offence a mug of cold water to be poured down the offender's sleeve by the other scouts." 30 The quotation illustrates how discipline was directed towards the body, while also making the act of punishment a collective experience.

26 Klas Sandell, Scoutings ekostrategi: Från "naturromantik" till "miljöproblem:" Natur, miljö och friluftsliv under 1900-talet i Svenska scoutförbundet (Stockholm: Institutet för framtidsstudier, 1990); Benjamin Jordan, Modern Manhood and the Boy Scouts of America: Citizenship, Race, and the Environment, 1910-1930 (Chapel Hill: University of North Carolina Press, 2016), 8-10; Nelson R. Block, "A Well Where Others May Drink: 100 Years of Scouting History," in Scouting Frontiers: Youth and the Scout Movement's First Century, ed. Nelson R. Block and Tammy M. Proctor (Newcastle: Cambridge Scholars, 2009), 10.

27 Original quote: "Kväll efter kväll av marschövningar och vändningar på en skolgård." Quoted in: "Förr och nu - några 25-åringar har ordet," Totem, no. 9-10 1936, 146-67.

28 Lundberg (2018), 55-95; Klas Sandell and Sverker Sörlin, "Naturen som fostrare: Friluftsliv och ideologi i svenskt 1900-tal," Historisk tidskrift 114, no. 1 (1994), 4-41; Sidebäck (1992), 99-137.

29 Sophie Wittemans, "The Double Concept of Citizen and Subject at the Heart of Guiding and Scouting," in Scouting Frontiers: Youth and the Scout Movement's First Century, ed. Nelson R. Block and Tammy M. Proctor (Newcastle: Cambridge Scholars, 2009); Carey Watt, "'No Showy Muscles:' The Boy Scouts and the Global Dimensions of Physical Culture and Bodily Health in Britain and Colonial India," in Scouting Frontiers: Youth and the Scout Movement's First Century, ed. Nelson R. Block and Tammy M. Proctor (Newcastle: Scholar's Press, 2009).

30 Baden-Powell (2004 [1908]), 46. 


\section{The issue of discipline at Åvatyr}

Let us now turn to the events at the Åvatyr camp in 1950. Since its inception in 1912, the Swedish Scout Association had arranged national scout camps at irregular intervals: in 1912, 1914, 1923, 1927, 1931 and $1938 .{ }^{31}$ No national camps were held during the world wars. After the end of the Second World War, a new camp was held in Gränsö in 1946. This event sought to bring back scouting to its romantic, joyful roots. The motto was: "The campfires are waiting." ${ }^{32}$

However, the atmosphere of demobilisation after the war seemed to affect the Swedish Scout movement. Interest in uniformed youth activity was in decline. During the latter half of the 1940s, membership figures stagnated after two decades of steady growth. To make matters worse, two of the leading figures of Swedish Boy Scouting, Prince Gustaf Adolf and Folke Bernadotte, died in 1947 and 1948 respectively.

Thus, the Åvatyr camp in 1950 was symbolically important. It was planned to become the largest Swedish Scout camp to date and the new leadership of the Swedish Scout Association hoped to carry on the cheerful spirit from the Gränsö camp. The name Åvatyr was a play of words on the nearby locations Åva and Tyresö, but also a pun on äventyr, the Swedish word for "adventure." The spirit of adventure and a camp environment that aimed to capture historical Swedish "authenticity" were among the traits that awaited the participants from all parts of Sweden. Additionally, roughly 1,000 foreign guests took part in the camp.

The opening ceremony of the camp was held on July 23 . As mentioned, the event was presented favourably in the major Swedish newspapers. In its front-page article, Dagens Nyheter gave specific mention to the speech delivered by the chairman of the organisation, Lennart Bernadotte, and his description of scouting as an international movement for peace. ${ }^{33}$

On July 25, another article in Dagens Nyheter featured updates from the camp. It mentioned, in passing, that the camp direction had issued its first punishments. The article stated that thus far, only one of roughly 10,000 participants had been found guilty of violations against camp statutes. It was a boy who had thrown paper "somewhat recklessly," and therefore received his punishment in public: one litre of cold water poured down each of his trouser legs. ${ }^{34}$

Nothing in this short news item signalled indignation or outrage. On the contrary, the incident of punishment was recounted in light-hearted prose, typical of amusing camp anecdotes. However, an editorial column in the evening paper Expressen interpreted the incident differently. It accused the Scout movement of being immune to modern and "reasonable" ideas of nurture and education: "If a young lad throws

31 The 1938 Tullgarn camp was jointly arranged by all member associations of Svenska Scoutunionen, "The Swedish Boy Scout Union." Fredrik Adelsköld, "Förbundsläger - en översikt," Totem, no. 7 $1938,101$.

32 Totem, no. 6, 1946, 113.

33 Dagens Nyheter, July 24, 1950.

34 "Laglydnaden är stor i scouternas Åvatyrläger, och hittills är det bara en av de omkring 10.000 deltagarna som ertappats med brott mot lägerstadgarna. Det var en liten krabat som kastat papper omkring sig litet vårdslöst, och på måndagen undfick han sitt straff offentligen: en liter kallt vatten i vardera byxbenet. // För den fortsatta rättsskipningen kommer en borgmästare att utses." Dagens Nyheter, July 25, 1950, 4. 
paper, let him for God's sake pick it up again, but why force him to public humiliation? It resembles bullying." ${ }^{35}$

Reaction was immediate. Within a few days, the camp's custom-installed telephone was ringing off the hook. All major Swedish newspapers discussed the possible signs of bullying and hazing within the Boy Scout movement. On the following day, Dagens Nyheter once again featured a report from the Åvatyr camp on its front page, but this time it was not in the jovial tone from the opening ceremony. The headline was: "Parents united against methods at Åvatyr." ${ }^{36}$ The reporter stated that boys who tried to escape from dishwashing duties were put in the stocks and that every village or district at camp had chosen "its own 'executioner." 37

The newspaper also reported that the previously mentioned punishment of pouring water down a boy's trouser legs had resulted in many angry or worried parents calling the camp directors. No similar punishments had been issued since then, but the paper also concluded that it was impossible to determine whether this was a result of a sudden shift in attitude towards more humane educational ideals, or a result of pressure from public opinion. ${ }^{38}$

The same day, Expressen renewed its attack on the "inhumane punishments" at Åvatyr. The unsigned editorial claimed that this was a matter of conservative versus progressive forces in society. ${ }^{39}$ Dagens Nyheter also followed up on their report. An article on July 27 declared that the stock used for punishments was in fact a prank, donated by the fathers of a Scout district in Örebro, who wanted to send their boys to camp with something fornsvenskt, "ancient Swedish," in accordance with the theme of the camp. The camp headquarters also denied any signs of bullying and instead made clear that all punishments were in fact cheerful consequences in the spirit of kamratfostran (literally: "fostering by peers;" the term could be used to describe peer socialisation as well as repressive acts hazing or bullying). The reporter confirmed that no signs of fear were present at camp. ${ }^{40}$

The editorial board of Expressen was not convinced, however. In its next editorial, the newspaper made a reference to an ongoing case of harassment at a Swedish military regiment. The idea of self-governance as an educational method among children might seem virtuous but lacked a clear distinction from bullying, argued the paper. Also, if the penalties issued at camp were merely jokes, how could they possibly deter anyone from further misconduct? ${ }^{41}$

No systematic attempt was made to ask the children participating in the camp about their thoughts and feelings in the matter. For historians of childhood it is notoriously difficult to find children's voices in archives. However, the incidents of punishment were discussed in at least one camp journal. ${ }^{42}$

35 “Om nu en liten grabb slänger papper omkring så låt honom i herrans namn plocka upp dem igen, men varför låta honom undergå offentlig schavottering? Det är snudd på pennalism.” Expressen, July 25, 1950, 2.

36 "Enig föräldraopinion mot Åvatyrmetoder," Dagens Nyheter July 26, 1950, 1, 22.

37 “Sin egen 'skarprättare." Dagens Nyheter, July 26, 1950, 22.

38 Ibid.

39 Expressen, July 26, 1950, 2.

40 Dagens Nyheter, July 27, 1950, 20.

41 Expressen, July 27, 1950, 2.

42 The issue of children's voices in archival research is addressed in: Kristine Alexander, "Can the Girl Guide Speak? The Perils and Pleasures of Looking for Children's Voices in Archival Research," Jeunesse: Young People, Texts, Cultures 4, no. 1, (2012), 132-45. 
One of the many Scout patrols that attended the Åvatyr camp was Hackspetten ("The Woodpecker") from Eslöv in Southern Sweden. The patrol also kept a handwritten camp journal, which details some of the events at the camp from the perspective of the participants at camp. On the third day of the camp, officially labelled stigfinnardagen, ("Pathfinder Day"), the famous Scout leader Torvald Wermelin, known by his Scout name Långa Lassot ("The Long Lasso"43) paid a visit to the patrol. The boys asked him for an autograph (as evident from the pages of the journal).

When he had written it, he sat among ten scouts, including P.L [Patrol Leader] and Lasse. He made us promise that if we saw someone throw paper [on the ground], we would kick him in the lower back, pad his back and say: "With kind regards from Långa Lassot." He then shook hands with each of us. ${ }^{44}$

The patrol members seem to have taken the senior Scout official at his word. While there is no mention of kicking, a few pages later the Hackspetten journal features a black-and-white photograph of a boy smiling, with his feet placed in the stocks. In his hands, he holds a glass of water and a piece of crispbread. The caption reads: "Lasse in the stocks for having thrown paper." ${ }^{45}$

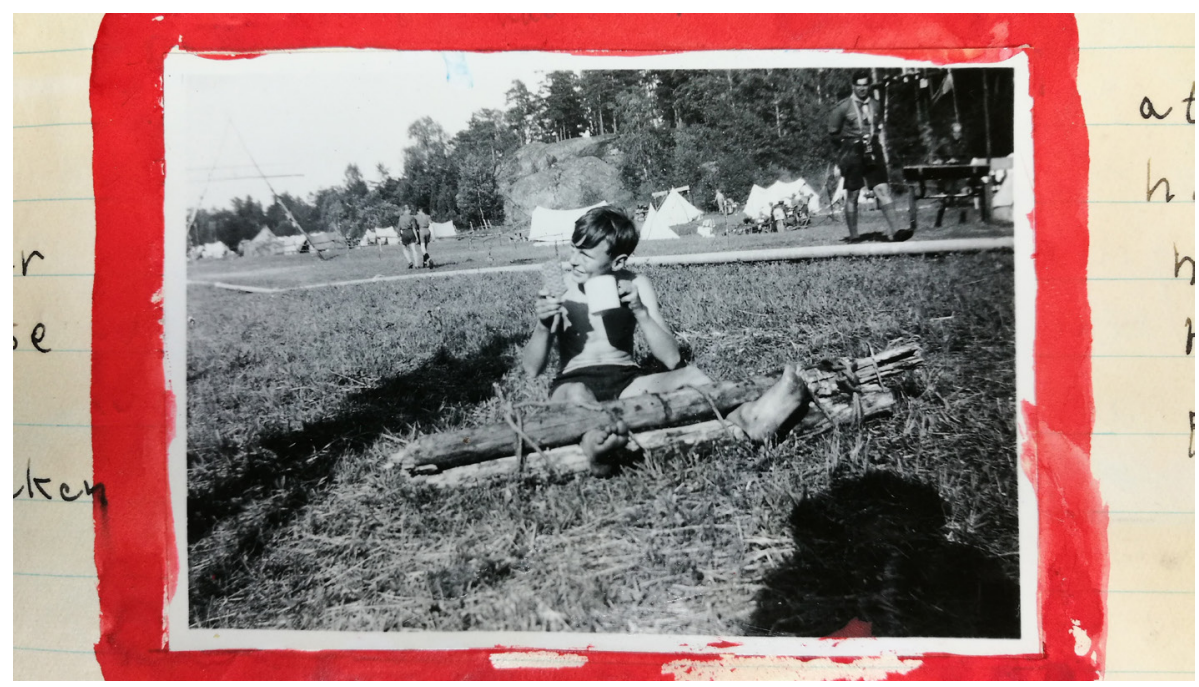

Figure 1. Photograph from Hackspetten (with permission of Skånes arkivförbund). Source: Hackspetten, Logbook, Eslövs Scoutkår, D3:2, Skånes arkivförbund, Landsarkivet, Lund.

The anecdote from the camp journal establishes a connection between the camp directors' attempts to combat excessive littering and the punishments mentioned

43 During the years around the Second World War, several high-ranking Swedish Scout officials were known by Scout names inspired by Wild West lore or Native American imagery: Sitting Bull, Emado-yena, Blå skuggan ("Blue Shadow"), Örnöga ("Eagle Eye”) etc. Scouten, no. 8, 1945, 197.

44 "När han skrivit satt han mitt bland ett tiotal scouter däribland P.l. och Lasse. Han slöt ett förbund med oss och vi lovade att om vi såg någon kasta papper skulle vi sparka honom i ryggslutet och klappa honom på ryggen och säga "med vänliga hälsningar från Lassot”. Därefter skakade han hand med oss allesamman." Hackspetten, Logbook, Eslövs Scoutkår D3:2, Skånes arkivförbund, Landsarkivet, Lund.

45 "Här sitter Lasse i stocken för att han har kastat papper," ibid. 
in the press. Judging from the boy's smile, the setting of the photograph and the caption, the punishment had been conducted in a cheery manner (which of course is not to say that the event was experienced that way by all participants). This view was also stressed by deputy Scout chief Bengt Junker who defended the events in the Scout leader magazine Totem: "Naturally, the stocks was never used for its original purpose, but many boys found it amusing to be fastened in it while posing for photographs." ${ }^{36}$ The other events were described as trifles or pranks that had been entirely misunderstood by the press.

This points to the fact that the newspapers, rather than internal criticism, acted as agents of change in this particular case, calling into question disciplinary practices from an outside position relative to the organisation. The imperative of change brought on by the mass media illustrates how this external gaze forced the organisation to adapt its practices due to changing social norms. Whereas the newspapers raised sharp criticism against the acts of punishments, the aforementioned camp journal did not, which highlights the relative importance of media pressure in this instance.

\section{Punishment and self-governance}

As previously mentioned, the Boy Scouts' educational scheme stressed the importance of activity and self-reliance, with patrols acting as units enjoying a certain degree of self-government under the leadership of a patrol leader. In order to understand how the acts of punishment fitted into this system of instruction and why the Åvatyr case was framed as a scandal, attention must be given to the practices of governance at camp. First, the carnivalesque setting and its play upon medieval justice, highlighted in both newspaper articles and the camp journal, should not be overlooked. The stocks were a symbol of medievalism, not only in form but also as to how punishment was conducted and displayed. The punishments, as described in the newspaper articles and the camp logbook, were all publicly displayed physical punishments, while simultaneously reflecting the "happy" atmosphere of camp. However, the examples of punishments discussed here can still be interpreted as disciplinary to some extent, and were all related to a specific offence, a form of behaviour that was to be altered. From the perspective of "economy of punishment," the aforementioned acts appear to be ineffective. The question posed by Expressen is relevant: If the punishments were indeed only intended to be amusing, in what way were they possibly effective as correctional measures? In other words, if no elements of shame or pain were involved, wouldn't the jovial character of punishment instead encourage misbehaviour?

Another crucial element of these punishments should be noted, namely, they were partly or wholly carried out with the young participants as co-actors. In that regard, they reflected the educational ideals of the Scout movement that gave the patrols a certain degree of autonomy and sought to make children active members of a community.

Swedish Boy Scout camps were not conceived of as democratic institutions, but the idea of self-governance of patrols had gradually gained popularity during the 
inter-war era. ${ }^{47}$ In the post-war era, these tendencies grew stronger. The Swedish educational system was reframed in a series of reforms that aimed to teach children to become critically thinking, democratic citizens rather than loyal subjects. ${ }^{48}$ The idea of self-government was also present in popular culture. For example, the Hollywood films Boys Town (1938) and Men of Boys Town (1941), starring Mickey Rooney and Spencer Tracy, presented the progressive juvenile institution of the same name in Nebraska, USA, which was governed by its habitants. It was hardly a coincidence that the new edition of the Boy Scout camp handbook Lägerliv, published in 1952, included a chapter titled Lägret: En pojkstad ["The Camp-A Boys' Town"]. However, the Swedish Boy Scout programme differed in notable fashion from the radical ideal of self-governance in the original Boys Town. Instead, the book noted that all participants at camp would not be aware of the fact that their camp was designed as an arena for practical education in citizenship. ${ }^{49}$ Instead of governing, the boys were to be primarily trained in cooperation through the building processes at camp: "[Camp] is built the same way every vigorous society must be built, based on individual initiative, enterprise and accountability. Through the entire process, the objective is clear: the accomplishments of the individual serve the benefit of all." 50

There were also initiatives to introduce acts of governing at Boy Scout camps, for example by giving the leaders a day off, and instead letting the children rule camp for a day. Even then, the practical or mundane chores of camp life such as cooking or providing shelter were thought of as more important than a democratic decision-making process..$^{51}$

Nevertheless, institutions of law and order were integral aspects of larger Scout camps, contributing to the realism of camp as a miniature society. Large camps regularly included a voluntary force of patrolling guards or a "police force." 52 By making children participants in the judicial process, it served to teach them practical citizenship and teach them self-discipline by correcting undesirable behaviour such as littering or cursing. Therefore, camp leaders defended accusations of bullying or excessive punishments by instead highlighting that the actions were part of a programme for kamratfostran.

The sentences conducted at the Boy Scout camps were by no means a unique phenomenon. As shown, Robert Baden-Powell had advised similar punishments for those who breached regulations or prescribed conduct among Scouts in his book Scouting for Boys. The Boy Scout camp at Gränsö in 1946 had also featured the stocks

47 Joakim Landahl, Stad på låtsas: Samhällssimulering och disciplinering vid Norra Latins sommarhem 1938-1965 (Göteborg: Daidalos, 2013).

48 Gunnar Richardson, Drömmen om en ny skola: Idéer och realiteter i svensk skolpolitik 1945-1950 (Stockholm: Liber/Allmänna förl., 1983); Tomas Englund, Skolan och demokratin (Uppsala: Pedagogiska institutionen, 1985).

49 "Kanske är det inte till alla delar medvetet för scouterna, att deras sommarläger blev en skola i praktiserad medborgarkunskap," Lennart Wennerström, Lägerliv (Stockholm: Sveriges scoutförbund, [1928]1952), 10.

50 "Den byggs som varje sunt samhälle måste byggas, nämligen på grundval av den enskildes handlingskraft, företagsamhet och ansvarskänsla. Hela tiden är målet klart: den enskilda prestationen ställs i det helas tjänst." Ibid., 7.

51 Totem, no. 4 1954, 59.

52 Scouternas arkiv- och museistyrgrupp, “Sveriges Scoutförbund Gränsö 1946," http://scouthistoria. ssf.scout.se/scouthistoria/ss/Granso_1946.pdf. 
as a (purportedly) cheery method for punishment. In fact, the yearbook Svenskt Scoutliv, which was distributed to the sponsors of the Swedish Scout movement, featured among the pictures that commemorated the Gränsö camp a photograph of a smiling boy placed in the stocks. It is reasonable to assume that this picture would not have been included in the publication if the scene had been thought of as problematic. ${ }^{53}$

According to Joakim Landahl, educational systems based on self-government often included some form of judicial institution. In his research on a summer home for boys in Sweden, Landahl describes the proceedings of its court system as a distinct genre of jest-sentences (skämt-straff). ${ }^{54}$ Landahl relates this to a form of power operation labelled "ambivalent power," in which children were simultaneously empowered and infantilised..$^{55}$

Evidently, this combination of play and earnestness was also present at the Åvatyr Scout camp. The concept of ambivalent power makes it possible to interpret these events not solely as acts of disciplinary power or corporal punishment, but rather an ambiguous system of governing over children that included discipline and self-governance.

Finally, it is worth noting that the aforementioned punishments were all directed towards the body in some degree, which was consistent with the Boy Scouts' citizenship training scheme that focused on the inculcation of desirable habits. Moreover, the spectacle of punishment highlighted to all participants, not only those who were punished, the unwanted nature of certain behaviour.

\section{Discipline, masculinity and Boy Scout reform}

The national media attention given to the educational and disciplinary methods of the Åvatyr camp seem to have caught the leaders of the Swedish Boy Scout movement off-guard. When the camp was over, it was clear that what was originally intended to become a great publicity event had backfired. While the camp was deemed an organisational success, the media attention given to a camp of this size had proven to be a double-edged sword. After Åvatyr, the Swedish Scout Association abandoned the idea of national camps for more than a decade. Instead, the following nationwide camps, in 1955 and 1959 respectively, were divided into six smaller camps located in different parts of Sweden..$^{56}$

More importantly, the events at Åvatyr sparked a debate about the masculine ideals of the Boy Scout movement, which in turn resulted in major co-educational reform a decade later. The events at Åvatyr confronted the Boy Scout methods of citizenship training with changing attitudes in society towards the government of children. In the decades following the Second World War, the idea of rule by force was increasingly called into question in public debate. According to previous research, corporal punishment of children became a publicly contested issue in the late 1940s

53 Svenskt Scoutliv 1947 (Stockholm: Sveriges Scoutförbund, 1947), 65.

54 Landahl (2013), 212.

55 Ibid., 340.

56 Georg Sterzel and Raoul Neveling, Skördetid och framtidstro (Stockholm: Förening Scoutmuseets vänner årsskrift, 2005), 16-20; Gerd Ek and Rolf Bergqvist, Förbundsläger (Stockholm: Förening Scoutmuseets vänner årsskrift, 1992). 
and early 1950s. In 1947, a government commission on education proposed a ban on physical punishment in Swedish primary schools. This sparked a debate on disciplinary measures against children that ultimately led to a complete ban in $1958 .{ }^{57}$ Swedish newspapers were generally in favour of the ban, especially liberal-leaning publications like Expressen, although it was common to also highlight the need for other correctional measures. ${ }^{58}$ The historian Jonas Qvarsebo has argued that two principal positions could be noted in this debate. The first stressed that children must be taught obedience, order and politeness to regain moral fortitude. Effective disciplinary measures were a necessary element. The other position took aim at a democratic citizenship ideal. From this viewpoint, physical punishments constituted an obstacle to the realisation of the individual autonomy and responsibility. ${ }^{59}$ In the aftermath of the Second World War, the recent European experiences of fascism and National Socialism provided a backdrop to this debate on corporal punishment of children. Democratic citizenship was framed as a counter-measure to authoritarian ideals of education and society. ${ }^{60}$

After the conclusion of the Åvatyr camp, Deputy Scout Chief Bengt Junker wrote an article for the Scout leaders' magazine Totem, in which he concluded that there were important lessons to be learned from the Àvatyr debacle. Most notably, the Scout movement had to improve its communication with society in general to attain stronger public support. Otherwise, the Scout movement would soon become outdated. ${ }^{61}$ A year earlier, Junker had participated in a debate on Swedish public radio with Sven-Arne Stahre, chairman of the labour youth organisation Unga Örnar ("Young Eagles"). Stahre had vigorously attacked the Boy Scout educational ideal for being out-dated. Instead of preparing children for the realities of democratic life, it merely gave boys a romantic background for adventures. Stahre contrasted with the ideals of his own organisation, which conducted co-educational training. In his mind, girls in general could easily expose war games and other militaristic elements as pathetic. ${ }^{62}$

While Junker defended the position of the Boy Scouts in this debate, he would nevertheless go on to call for increased cooperation between Boy Scout and Girl Scout organisations to strengthen citizenship. The following year, Junker was elected chairman of the Swedish Boy Scout Association. In a speech delivered at the Stockholm City Hall in 1951, he described the need for modernisation of the Boy Scout programme. Junker declared: "nothing could be more dangerous than to promote an unrealistic masculine ideal for our scouts." ${ }^{63}$ Democratic society, concluded Junker, was founded on cooperation between men and women. Therefore, Boy Scouting needed to better prepare its members for this reality through increasing cooperation

57 Stig Munknäs, Tidningspressen och den nya skolan: En studie av tidningsdebatten under skolans reformperiod åren 1946-1962 (Stockholm, 1983), 93.

58 Ibid., 98-104.

59 Jonas Qvarsebo, Skolbarnets fostran: Enhetsskolan, agan och politiken om barnet 1946-1962 (Linköping: Tema Barn, Linköpings universitet, 2006), 81-82.

60 Ibid., 58.

61 Bengt Junker, “Presstormen kring Åvatyr," Totem, nos. 6-7 1950, 123.

62 Sven-Arne Stahre, "Kritisk syn på scouting," Örnledaren, nos. 1-2, 1950, 11.

63 Bengt Junker, "Jubileumstal vid Sveriges scoutförbunds 40-årshögtid i Blå hallen den 17 nov 1951," Svenskt scoutliv 1952 (Stockholm: Sveriges Scoutförbund 1952), 24. 
with the Girl Scouts. This was a clear demarcation from Boy Scout rhetoric prior to 1945, when excessive feminine influence was regarded as an impediment to the manly training of young Boy Scouts. ${ }^{64}$

Regarding another Swedish outdoor organisation, Friluftsfrämjandet, Petra Rantatalo has noted that organised outdoor activities for children after the Second World War became less adventurous and arduous, focusing instead on family orientation. Activities were conducted closer to home and less physically demanding, which can be described as a process of domestication of outdoor life. ${ }^{65}$

In the Boy Scout movement, the domestication process coincided with changing notions of masculinity, which could be noted also in outdoor activities. "Hard scouting," which had been a word with positive overtones before 1945, became frowned upon. ${ }^{66}$ During the 1950s, scouting was framed as a family venture. For the large Scout camps that were arranged in the summer of 1959, parents were invited to join at separate camp areas. ${ }^{67}$

When friluftsliv was no longer envisioned as an arena for manliness per se, the justification for gender-segregated Scout organisations became less apparent, thus making a shift towards co-educational scouting in Sweden possible. In 1953, the first co-educational Scout camp with troops from the Swedish Scout Association and the Swedish Girl Scout Association (Sveriges Flickors Scoutförbund) was held at Korgil. ${ }^{68}$ During the 1950s, many scout troops of senior age (roughly 15-18 years of age) were partly or fully gender-integrated. Meanwhile, Bengt Junker reiterated that the goal of the Boy Scout movement was not to produce men, but fellow humans. ${ }^{69}$ This process of increased cooperation culminated in 1960, when the Swedish Scout Association merged with the Swedish Girl Scout Association. The process was multi-faceted, but the changing masculine ideal of the Boy Scout movement was undoubtedly an important element. It is worth noting, however, that changes in masculine ideals did not automatically call for co-educational change, but rather helped to counter the arguments against increased cooperation between Boy Scouts and Girls Scouts. ${ }^{70}$

\section{Conclusions}

Earlier research into the relationship between childhood and violence in post-war Sweden has accentuated the changing norms and legislation regarding corporal

64 Examples can be found in: Lennart Wennerström, "Friluftsliv och scouting," Svenskt Scoutliv 1930, Stockholm: Sveriges Scoutförbund, 1931), 83; Carl Svedelius "Ut i skog och mark, ut i Guds fria natur," Svenskt Scoutliv 1936 (Stockholm: Sveriges Scoutförbund, 1937), 68.

65 Petra Rantatalo, “Skogsmulleskolan," in Friluftshistoria: Från "härdande friluftslif” till ekoturism och miljöpedagogik, ed. Klas Sandell and Sverker Sörlin, 2nd edition (Stockholm: Carlssons, 2008), $138-55$.

66 An example can be found in Samspel, no. 5 (1958/59), 90.

67 "Scoutföräldrar på sommarläger," Totem. no. 2 1954; "Vuxenmedverkan på L-59," Samspel, no. 3 1959/60, 58.

68 Treklövern, no. 7 1953, 118; Bengt Kullström, “Korgil - ett försök till samscoutläger," SFS Ledarblad, no. 8 1953, 95; Korgil, Camp dossier, Läger: diverse, N:6, Diverse läger 1951-60, Sveriges Flickscoutförbunds arkiv, Riksarkivet.

69 Bengt Junker, “Kvinnligt - manligt - mänskligt," Samspel, no. 5 1958/59, 90.

70 Björn Lundberg, "Scouting at Home: Family Virtues and Domestic Ideals in the Swedish Scout Movement 1910-1960," Paper presented at the Society for the History of Children and Youth Conference, Vancouver, Canada, June 24-26, 2015. 
punishment in schools. Scholars have argued that new discourses on childhood accentuated the vulnerability of children. Their need of protection, not only from wrongdoing adults but also from mischievous peers, became increasingly important.

This article has examined the reports of physical punishment at the Swedish Boy Scout camp Åvatyr in 1950. While major Swedish newspapers described the events as institutionalised forms of bullying and violence, the camp directors declared that the incidents were merely innocent jokes. By analysing the reported events as parts of the process of governing, the aim has been to explain the events in the context of citizenship instruction rather than attempting to examine whether or not the acts were perceived as just or amusing by those involved.

The argument in this article has been that the public outcry against the events at the camp reflected a change in post-war society that caught the Boy Scout leadership off-guard. The corporality of Boy Scout education, its notions of masculinity and the ambivalent power evident in the acts of camp justice came into contrast with increasing demands for a citizenship education based on democracy and individual autonomy. This also serves to explain why the punishments at Åvatyr sparked a debate within the Boy Scout association that ultimately led to new interpretations of masculine ideals.

In this process, the separation of boys and girls into different organisations was called into question. Cooperation between Boy Scouts and Girl Scouts was presented by Bengt Junker, chairman of the Swedish Scout Association, as a guarantee for the promotion of human, rather than manly, virtues. During the summer of 1953, the first co-educational camp was arranged.

Another tendency within the association for Boy Scouts was a domestication of the friluftsliv-tradition, including a family-oriented approach. The increased involvement of parents was to a certain extent conceived of as a means to address the issue of how and where to find future scout leaders and other organisational issues, but the increased involvement of parents was a different approach to governance at camp compared to the "boys' town" ideal that had stressed elements of self-governance. 


\section{References}

Periodicals

Aftonbladet.

Expressen.

Dagens Nyheter.

Örnledaren.

Samspel.

Svenskt Scoutliv.

Totem.

Treklövern.

\section{Other sources and literature}

Alexander, Kristine. "Can the Girl Guide Speak? The Perils and Pleasures of Looking for Children's Voices in Archival Research." Jeunesse: Young People, Texts, Cultures 4 , no. 1, (2012), 132-45.

Baden-Powell, Robert. Aids to Scoutmastership: A Handbook for Scoutmasters on the Theory of Scout Training. London: Jenkins, 1919.

Baden-Powell, Robert. Scouting for Boys: A Handbook for Instruction in Good Citizenship—the Original 1908 Edition. Oxford: Oxford: Oxford University Press, 2004.

Blackman, Lisa. The Body. Oxford: Berg, 2008.

Block, Nelson R. "A Well Where Others May Drink: 100 Years of Scouting History." In Scouting Frontiers: Youth and the Scout Movement's First Century, edited by Nelson R. Block and Tammy M. Proctor, 2-12. Newcastle: Cambridge Scholars, 2009.

Block, Nelson R., and Tammy M. Proctor, eds. Scouting Frontiers: Youth and the Scout Movement's First Century. Newcastle: Cambridge Scholars, 2009.

Bonhomme, Jeffrey. "In Step with Canada's Future:" The Restructuring of the Boy Scout Movement in Canada" (1992). Electronic Theses and Dissertations 6833.

Dean, Mitchell. Governmentality: Power and Rule in Modern Society. Thousand Oaks, CA: SAGE Publications, 2010.

Dean, Mitchell. "Liberal Government and Authoritarianism." Economy and Society 31, no. 1 (2002), 37-61.

Ek, Gerd, and Rolf Bergqvist. Förbundsläger. Föreningen Scoutmuseets Vänner, Årsskrift. Stockholm: Svenska Scoutförbundet, 1992.

Englund, Tomas. Skolan och demokratin. Uppsala: Pedagogiska institutionen, 1985.

Formark, Bodil. Den välsituerade flickan: Om den svenska flickscoutrörelsens historia 1910-1940. Lund: Sekel, 2010.

Foucault, Michel. Discipline and Punish: The Birth of the Prison, translated by Alan Sheridan. New York: Vintage Books, 1979.

Foucault, Michel. "Governmentality." In The Foucault Effect: Studies in Governmentality, edited by Graham Burchell, Colin Gordon, and Peter M. Miller. Chicago: University of Chicago Press, 1991.

Foucault, Michel. Security, Territory, Population: Lectures at the Collège De France, 1977-1978. New York: Palgrave Macmillan, 2007.

Gordon, Colin. “Governmental Rationality: An Introduction.” In The Foucault Effect: Studies in Governmentality, edited by Graham Burchell, Colin Gordon, and Peter M. Miller. Chicago: University of Chicago Press, 1991. 
Gustafsson, Karl Erik and Per Rydén, eds. Den svenska pressens historia. 4, Bland andra massmedier. Stockholm: Ekerlid, 2002.

Hackspetten, Logbook, Eslövs Scoutkår D3:2, Skånes arkivförbund, Landsarkivet, Lund.

Helgren, Jennifer. American Girls and Global Responsibility: A New Relation to the World during the Early Cold War. New Brunswick: Rutgers University Press, 2017.

Holmberg, Claes-Göran, Ingemar Oscarsson, and Per Rydén. En svensk presshistoria. Stockholm: Esselte studium, 1983.

Jeal, Tim. The Boy-Man: The Life of Lord Baden-Powell. New York: Morrow, 1990.

Jordan, Benjamin. Modern Manhood and the Boy Scouts of America: Citizenship, Race, and the Environment, 1910-1930. Chapel Hill: University of North Carolina Press, 2016.

Korgil, Camp dossier, Läger: diverse, N:6, Diverse läger 1951-60, Sveriges Flickscoutförbunds arkiv, Riksarkivet.

Larsson, Anna. "Mobbningfrågan i förändring. Efterkrigstidens synsätt på skolbarns kamratrelationer." Historisk tidskrift 130, no. 2 (2010), 241-64.

Larsson, Esbjörn. "Barn från Mars: Skolungdomens vapenövningar.” Militärhistorisk tidskrift 2013.

Landahl, Joakim. Auktoritet och ansvar: Lärares fostrans- och omsorgsarbete $i$ historisk belysning. Stockholm: Arbetslivsinstitutet, 2006.

Landahl, Joakim. Stad på låtsas: Samhällssimulering och disciplinering vid Norra latins sommarhem 1938-1965. Göteborg: Daidalos, 2013.

Lundberg, Björn. "Scouting at Home: Family Virtues and Domestic Ideals in the Swedish Scout Movement 1910-1960." Paper presented at the Society for the History of Children and Youth Conference, Vancouver, Canada, June 24-26, 2015.

Lundberg, Björn. Naturliga medborgare: Friluftsliv och medborgarfostran i scoutrörelsen och Unga Örnar 1925-1960. Lund: Arkiv förlag, 2018.

Mills, Sarah. "Be Prepared: Communism and the Politics of Scouting in 1950s Britain." Contemporary British History 25, no. 3 (2011).

Mosse, George L. The Image of Man: The Creation of Modern Masculinity. Studies in the History of Sexuality. New York: Oxford University Press, 1996.

Munknäs, Stig. Tidningspressen och den nya skolan: En studie av tidningsdebatten under skolans reformperiod åren 1946-1962. Stockholm: s.n., 1983.

Östling, Johan. Nazismens sensmoral: Svenska erfarenheter $i$ andra världskrigets skugga. Stockholm: Atlantis, 2008.

Proctor, Tammy M. "On My Honour: Guides and Scouts in Interwar Britain." Transactions of the American Philosophical Society 92, no. 2 (2002), i-180.

Proctor, Tammy. Scouting for Girls: A Century of Girl Guides and Girl Scouts. Santa Barbara, CA: Praeger, 2009.

Puke, Margareta. Scoutings historia. Stockholm: Svenska Scoutförbundet, 1982.

Qvarsebo, Jonas. Skolbarnets fostran: Enhetsskolan, agan och politiken om barnet 1946-1962. Linköping: Linköpings universitet, 2006.

Rantatalo, Petra. "Skogsmulleskolan." In Friluftshistoria: Från "härdande friluftslif" till ekoturism och miljöpedagogik, edited by Klas Sandell and Sverker Sörlin, 2nd edition, 138-55. Stockholm: Carlssons, 2008.

Richardson, Gunnar. Drömmen om en ny skola: Idéer och realiteter i svensk skolpolitik 1945-1950. Stockholm: Liber/Allmänna förl., 1983. 
Rose, Nikolas. Governing the Soul: The Shaping of the Private Self. London: Routledge, 1989.

Rosenthal, Michael. The Character Factory: Baden-Powell and the Origins of the Boy Scout Movement. London: Collins, 1986.

Sandell, Klas. Scoutings ekostrategi: Från "naturromantik" till "miljöproblem:" Natur, miljö och friluftsliv under 1900-talet i Svenska Scoutförbundet. Stockholm: Institutet för framtidsstudier, 1990.

Sandell, Klas and Sverker Sörlin. "Naturen som fostrare: Friluftsliv och ideologi i svenskt 1900-tal." Historisk tidskrift 114, no. 1 (1994), 4-41.

Scouternas arkiv- och museistyrgrupp, "Sveriges Scoutförbund Gränsö 1946," http:// scouthistoria.ssf.scout.se/scouthistoria/ss/Granso_1946.pdf.

Sidebäck, Göran. Kampen om barnets själ: Barn- och ungdomsorganisationer för fostran och normbildning 1850-1980. Stockholm: Carlsson, 1992.

Sjöberg, Mats. "Att fostra ett skolbarn: Den nya skolan och barndomens förändring 1950- 1970." In Barnets bästa: En antologi om barndomens innebörder och välfärdens organisering, edited by Bengt Sandin and Gunilla Halldén. Stockholm/ Stehag: Symposion, 2003.

Sterzel, Georg, and Raoul Neveling. Skördetid och framtidstro. Stockholm: Föreningen Scoutmuseets vänner årsskrift, 2005.

Svedelius, Carl. "Ut i skog och mark, ut i Guds fria natur." Svenskt Scoutliv 1936 (1937).

Sveriges flickors scoutförbunds historia 1913-1953, Instruktionsserie för ledare 6. Stockholm: Sveriges flickors scoutförbund, 1954.

Voeltz, Richard A. "The Antidote to 'Khaki Fever'? The Expansion of the British Girl Guides During the First World War." Journal of Contemporary History 27, no. 4 (1992), 627-38.

Warren, Allen. "'Mothers for the Empire': The Girl Guides Association in Britain 1909-1939." In Making Imperial Mentalities: Socialisation and British Imperialism, edited by J.A. Mangan. Manchester: Manchester University Press, 1990.

Warren, Allen. "Sir Robert Baden-Powell, the Scout Movement and Citizen Training in Great Britain, 1900-1920." The English Historical Review 101, no. 399 (1986), 376-98.

Watt, Carey. 'No Showy Muscles:' The Boy Scouts and the Global Dimensions of Physical Culture and Bodily Health in Britain and Colonial India." In Scouting Frontiers: Youth and the Scout Movement's First Century, edited by Nelson R. Block and Tammy M. Proctor, 121-42. Newcastle, 2009.

Wennerström, Lennart. "Friluftsliv och scouting." Svenskt Scoutliv 1930 (1931).

Wennerström, Lennart. Lägerliv. Stockholm: Sveriges scoutförbund, [1928]1952.

Wittemans, Sophie. "The Double Concept of Citizen and Subject at the Heart of Guiding and Scouting." In Scouting Frontiers: Youth and the Scout Movement's First Century, edited by Nelson R. Block and Tammy M. Proctor, 56-71. Newcastle: Cambridge Scholars, 2009. 